\title{
Counterfactual Impact Evaluation of the Support under Measure "Procesas LT" in Enterprises of the Construction Sector
}

\author{
Laura Baroniene, Vytautas Zirgutis
}

Vytautas Magnus University

K. Donelaicio st. 58, LT-44248, Kaunas, Lithuania

E-mail.v.zirgutis@evf.vdu.lt

JSC "Bankines konsultacijos"

Savanoriu av. 192, LT-44151Kaunas, Lithuania

E-mail.laura.baroniene@gmail.com

cross $^{\text {ref }}$ http://dx.doi.org/10.5755/j01.ee.28.4.13718

Competitiveness of the State and social welfare are closely related to the effective use of production factors. Organisations that have achieved higher level of labour productivity are more competitive and beneficial for the State and society. Modern management methods have positive impact on labour productivity, therefore their application is supported. One of the promotion measures is "Procesas LT", under which business organisations are granted non-refundable subsidies for the implementation of modern management methods to increase labour productivity. Administrative institutions make decisions about granting funds of this promotion measure for the projects of business organizations, not taking into account macroeconomic factors that influence labour productivity as well. It has been determined that the counterfactual impact evaluation of this measure can be carried out in the enterprises that have been granted the support. The counterfactual impact evaluation of measure "Procesas LT" has been conducted as an empirical research in the enterprises of construction sector that have implemented the Occupational Health and Safety Management System in accordance with the requirements of standard OHSAS 18001.

The authors of the research acknowledge Public Institution Lithuanian Business Support Agency for cooperation.

Keywords: Competitiveness, Productivity, Counterfactual Analysis, Procesas LT.

\section{Introduction}

Competitiveness of the State and social welfare are closely related to the created value added and effective use of production factors. Organisations that have achieved higher level of labour productivity are more competitive and beneficial for the State and society. Modern management methods have positive impact on labour productivity; therefore, their application should be supported. One of the promotion methods is "Procesas LT" - the measure of the Operational Programme for Economic Growth, under which considerable EU support funds have been distributed to increase labour productivity in business organisations. Effectiveness of use of the EU structural aids, granted in the form of non-refundable subsidies for the implementation of modern management methods to increase labour productivity, are evaluated according to the established achievement indicators of the measure; however, it is not known what these indicators would be, if subsidies were not granted.

In order to gain the support, enterprises undertake to implement the management method and increase labour productivity. But the level of obligations undertaken can vary from the extremely conservative (increase in labour productivity should be higher than the obligations, alone due to the macroeconomic factors affecting the sector) to the ambitious ones (increase in labour productivity should be much lower than the obligations, due to the macroeconomic factors affecting the sector).

In order to provide the support, Lithuanian Business Support Agency and the Ministry of Economy evaluate projects (and obligations of enterprises to increase labour productivity) and make decisions about granting funds, assessing projects from different sectors with the same criteria and not taking into account that the achievement of established indicators depends not only on the support funds, but also on other aspects, such as the macroeconomic factors.

These issues have prompted evaluating decisions from both sides - enterprises (to undertake obligations to increase labour productivity with the EU support) and public decision makers (to grant the EU support for projects) - eliminating macroeconomic factors and sector specific trends. Enterprises of the construction sector have been selected as a basis for the research.

This empirical research deals with the following problem: does the impact of measure "Procesas Lt" on the increase of labour productivity in the organisations of the construction sector was reasonable, excluding evaluation of other labour productivity factors evident in the sector?

The goal of the research is to evaluate the counterfactual impact of the measure "Procesas Lt" on labour productivity in enterprises of the construction sector. 
The research uses the methods of primary data analysis, logical analysis, extrapolation, counterfactual evaluation, benchmarking, analysis of scientific literature, and statistical analysis.

\section{Relevance and Conception of Labour Productivity}

A great number of theoretical and empirical studies have contributed to the discussions of the source of the economic growth (Borensztein \& Ostry, 1996; Chow \& Li, 2002; Krugman, 1994; Yu, 2010), debating which source, factor accumulation or total factor productivity improvement is the key growth-driving factor. Productivity shocks have been identified as the main driving factor of business cycles in small open economies (Garcia-Cicco et al., 2010). Cho and Cooley analyse the welfare effect of productivity shocks in a closed economy (Cho \& Cooley, 2005).

Some authors (Hulten, 2001; Syverson, 2011) use productivity as outcome variable of measuring efficiency in firm-level. Competition between companies requires increase in technical efficiency (TE), while also improving service productivity (Costa, 2012; Ostrom et al., 2010). Service productivity and perceived service quality are both critical success factors for companies (Marinova, Ye, and Singh, 2008). The service sector and the area of service research are facing with many undergoing changes. Many service companies are becoming more unstructured and, as a result, a number of traditional operations management techniques are less effective in improving their performances (Lee et al., 2011).

Productivity increases may result in improvements in company profitability (Capece et al., 2008; Costa et al., 2012; Biondi et al., 2013), high quality service increases the likelihood of customer loyalty, customer repurchase propensity and, again, company profitability at the same time (Yee et al., 2011).

The traditional concept of productivity in manufacturing may be defined as the ratio between outputs produced and inputs utilised, and constitutes a measure of the efficiency of a company (Biondi et al., 2013). The definition of productivity relies on the postulation of constant quality of outputs (Gronroos \& Ojasalo, 2004): productivity improves only if the quality of the increased number of outputs, equal inputs, is invariant with respect to the output quality before an increase in productivity occurs. However, with regard to the service sector, having technical efficiency as the only objective may result in a reduction in client-perceived quality and, thus an integrated vision of both efficiency and quality is necessary (Calabrese et al., 2013a). Change et al. showed that when programmes for management and quality monitoring are introduced, a simultaneous improvement in productivity is observed (Change et al, 2011). LeonLedesma et al. have explored the relationship between capital-labour substitution and technical bias in production with implications for production-function estimation under nonneutral technical change (Leon-Ledesma et al., 2010).

Laureti, Viviani found that productivity has a substantial effect on firm competitiveness in textile and clothing, machinery and mechanical equipment industries and it is stronger in 2002 than in 2005 (Laureti \& Viviani, 2011). These results support Porter's theory as they suggest that the competitiveness and the productivity of a firm are analytically related to each another.

A large number of studies have examined international technological or productivity convergence (Baumol et al., 1994; Barro \& Sala-i-Martin, 2004; Bernard \& Jones, 1996a, 1996b; Miller \& Upadhyay, 2002; Cameron et al., 2005). Most authors use regression techniques to test the relationship between countries' productivity growth rates and their initial productivity levels. Technological catch-up occurs when productivity grows faster in those countries with lower productivity levels (b convergence) (Ruan \& Gopinath, 2010).

Most studies confirm a positive relationship between innovation and company value. Innovative companies have a higher value and they are bigger, however differences in growth opportunities are not statistically significant for innovative and non-innovative companies (Berzkalne \& Zelgalve, 2012).

Makin, Strong shows new results of the Elasticity of Substitution (ES) between capital and labour and factor productivity for Australia, an economy which experienced major economic reform that substantially increased the flexibility of its labour, product and capital markets throughout the 1980s and 1990s (Makin \& Strong, 2013).

Competitiveness is "determined by productivity, and depends on firms' strategies, it is partially, the result of relationship between firms and local business environment, depends on social and economic objectives synergy and is influenced by factors from external environment" (Porter \& Ketels, 2003).

Labour productivity is "one of the most important synthetic indicators of the enterprise economic activity efficiency which reflects the effectiveness or the fruitfulness of labour expended in production", and its growth represents "the most important factor to increase output, reduce production costs and increase profitability and product competitiveness on domestic and foreign market" (Bondoc \& Hagiu, 2011). Development of SMEs requires a determined effort to reduce the gap between their productivity and the productivity of large companies (Manole et al., 2014).

The researches on assessment of the business conditions tend to identify the concepts of business conditions, competitiveness and business environment (Vijeikis \& Makstutis, 2009). Competitiveness of the State can be understood as the ability of the State to successfully compete in the international environment, as well as the social welfare expressed by the indices of economic productivity growth and standard of living (Stredna \& Zubkova, 2012).

According to the World Economic Forum (2012), international competitiveness can be described as "the set of institutions, policies, and factors that determine the level of productivity of a country" (The Global Competitiveness Report 2012-2013 (Schwab, 2013)).

Taking into account different perspectives, international competitiveness is linked with the low cost of labour or offering attractive geographic locations for new investments (Spencer, 2008). It captures a multitude of dimensions, covering issues associated with employment, productivity, economic growth, and income inequalities, level of education, political freedom, ability to assimilate innovation, and finally trade openness (Lechman, 2014). 
A country`s openness to international competition fosters increases in capital and labour productivity, technology transfers, and accessing new knowledge (Bernard et al., 2007). In a broad conceptual framework, international competitiveness can be seen through the lens of productivity, costs and market shares (Porter et al., 2008).

A large number of studies in the last years have examined several factors related with productivity, which confirms the relevance of this article: Yu explored how reductions in tariffs on imported inputs and final goods affect the productivity of large Chinese trading firms, with the special tariff treatment that processing firms receive on imported inputs ( $\mathrm{Yu}, 2015)$; $\mathrm{Yu}$ and $\mathrm{Li}$ analysed the impact of imported intermediate inputs on firms (Yu \& Li, 2014); $\mathrm{Hu}$ and Liu examined the impact of tariff reduction following China's World Trade Organization (WTO) entry on the productivity of Chinese manufacturing firms using a firm-level panel database that comprises all of China's manufacturing firms with an annual turnover above 5 million yuan and that spans the period of 2000-2006 (Hu \& Liu, 2014); Shepotylo and Vkhitov analysed the effect of services liberalization on total factor productivity (TFP) of manufacturing firms (Shepotylo \& Vkhitov, 2015); Preenen, Vergeer, Kraan and Dhondt developed and examined the idea that internal labour flexibility practices are beneficial for labour productivity and innovation performance of companies (Preenen et al., 2015); Hottenrott and Lawson discovered that the positive effect of public funding is driven by UK research council and charity grants and that EU funding has no significant effect on publication outcomes (Hottenrott \& Lawson, 2013); Rizov, Pokrivcak and Ciaian analysed the impact of the Common Agricultural Policy (CAP) subsidies on farm total factor productivity (TFP) in the European Union (EU) (Rizov et al., 2013).

\section{EU Support and Measure "Procesas LT"}

Hence, competitive economy can be defined as the economy, where the State, pursuing a long-term growth and welfare of the citizens, creates the environment for efficient enterprises capable of manufacturing products of higher quality and rendering services at lower prices (Results of Impact of the EU Structural Support on the Competitiveness of Lithuania, 2015). Competitiveness is influenced by the macro-level factors that depend on the competence of the State authorities and create a favourable environment for the competition of enterprises (tax measures, adoption or amendment of legislation, improvement of activities of the authorities), and the micro-level factors that directly affect the competitiveness of enterprises. Changes in the macrolevel factors are associated with the measures implemented at the national level and the impact of the international business environment, while the fluctuation of the microlevel factors can also be influenced by the investments of the EU Structural Funds that could amount to more than 23 billion of Litas in Lithuania during the financial period of 2007-2013. This amount is equal to one additional State budget (vs. the draft of the State budget expenditure as of 2007 amounts to app. 22 billion of Litas).

The priority "Increasing Business Productivity and Improving Business Environment" of the Operational
Programme for Economic Growth for 2007-2013 intends to increase the productivity of enterprises, to enhance the viability of operating enterprises and to encourage entrepreneurship. The Operational Programme for Economic Growth states that the "upon consideration of the rapid globalization-driven changes and implementation of the key goal, namely to ensure a long-term economic growth, the increase of labour productivity is possible only subject to constant application of product and process innovation, using the developed know-how and skilled workforce. The critical assumptions for the growth of productivity are improvement of the overall management level in enterprises in line with application of the advanced management methods, such as the quality management methods (ISO, EFQM, etc.), the flexible production (Lean, Toyota, etc.) and process optimisation techniques (e.g., Goldratt's system), the advanced management systems (e.g., Six Sigma)“.

Measure "Procesas LT" was supposed to contribute to implementation of the goal to increase the corporate labour productivity. The objective of the measure is to encourage small and medium-sized enterprises to introduce modern management methods and management systems, thus creating favourable conditions for increasing enterprise labour productivity and export. Supported activities: acquisition expenses of the external consulting services required for implementing modern management methods or management systems at a particular enterprise, except of personnel management systems. The tangible and intangible investments are not supported. The monitoring indicators of the measure implementation include, inter alia, increase in export and increase in labour productivity of the supported enterprises (Order No. 4-508 by the Minister of Economy of the Republic of Lithuania of June 1, 2012).

Within two invitation periods (in 2009 and 2012) the support of 11.4 million of Litas was allocated under this measure to 170 organisations. A significant proportion of these organisations (even 27) implemented the Occupational Health and Safety Management System in accordance with the requirements of international standard OHSAS 18001 (the data are provided in Table 1).

Table 1

Dissemination of the Organisations that Have been Granted the Support for the Implementation of OHSAS 18001 by Sectors

\begin{tabular}{|c|c|c|}
\hline $\begin{array}{l}\text { Ref. } \\
\text { No. }\end{array}$ & $\begin{array}{l}\text { Description of economic } \\
\text { activity }\end{array}$ & $\begin{array}{l}\text { Amount of the } \\
\text { organisations that have } \\
\text { been granted the support }\end{array}$ \\
\hline 1. & Publishing & 1 \\
\hline 2. & Machinery and equipment & 1 \\
\hline 3. & Other manufacturing & 1 \\
\hline 4. & Construction & 10 \\
\hline 5. & $\begin{array}{l}\text { Wholesale and retail trade; } \\
\text { repair of motor vehicles and } \\
\text { motorcycles, repair of other } \\
\text { personal and household goods }\end{array}$ & 3 \\
\hline 6. & $\begin{array}{l}\text { Transport, storage and } \\
\text { communication }\end{array}$ & 3 \\
\hline 7. & Engineering activities & 5 \\
\hline \multirow[t]{2}{*}{8.} & Other activities & 3 \\
\hline & Total: & 27 \\
\hline
\end{tabular}

Upon usage of the support funds of "Process LT", total 27 Occupational Health and Safety Management Systems have been implemented and certified in accordance with the 
requirements of OHSAS 18001 , amounting to $10.4 \%$ of all the Occupational Health and Safety Management Systems implemented and certified in accordance with the requirements of OHSAS 18001 in Lithuania during the period of 2010-2014. Within the scope of this measure the implementation and certification of 10 Occupational Health and Safety Management Systems compliant with the requirements of OHSAS 18001 have been financed in the construction sector, amounting to $6.7 \%$ of all the organisations operating in the construction sector, which had implemented and certified the Occupational Health and Safety Management Systems during the period under research.

The efficiency of the decisions to implement and certify the Occupational Health and Safety Management Systems in accordance with the requirements of international standard OHSAS 18001 by utilizing the support of the EU Structural Funds is expressed by the extent of the value added created per Litas / Euro of the EU Structural Funds spent, which is conditioned by changes in labour productivity.

The organisations that have been granted the support under measure "Procesas LT" record changes in export, turnover and labour productivity; however, the changes of these indicators are likewise observed in other enterprises that have not used the EU support, which are subject to the macroeconomic factors. There is no objective evidence showing to what extent these changes have been affected by the support funds, and to what extent - by other macroeconomic factors.

In the EU policy, the objective has been particularly evident to utilize the EU structural support to the utmost and to enhance the benefits of the programmes, in order to increase the effectiveness of the implemented measures and projects. Both in finalizing the implementation of the projects for the period of 2007-2013 and in programming the new period of use of the EU structural support of 20142020 , the evaluation methods will have to be progressively applied to allow justification of the benefits and necessity of the EU-funded investments.

The impact of the subsidies on the final result, excluding the impact of other factors, can be determined by the counterfactual impact evaluation that has so far been applied only once in Lithuania for evaluating the impact of the EU funds (the first large-scale analysis of the counterfactual methods for evaluating the impact of the EU support in Lithuania was the Evaluation of the Social Integration Services to Vulnerable and Socially Disadvantaged Persons, carried out in 2011).

The method of the counterfactual impact evaluation is applied within the scope of this research in order to evaluate the impact (the value added) of the subsidies granted under measure "Procesas LT" of the priority "Increasing Business Productivity and Improving Business Environment" of the Operational Programme for Economic Growth to the supported organisations.

\section{Methodology of the Research}

Counterfactual analysis is a quantitative evaluation method of the policy impact that allows estimating the net impact of the intervention. The counterfactual analysis aims at comparing the outcome achieved under the intervention with the outcome that would have been achieved in the absence of the intervention. The counterfactual impact evaluation is most suitable to assess the interventions intended to support enterprises (subsidies for business start or corporate development), to increase employment, as well as in the field of education. These interventions are most relevant for the counterfactual impact evaluation, as they are focused on behaviour change, homogeneous, repeatable and demonstrate a sufficient number of beneficiaries.

Counterfactual evaluation method is widely used in several areas: Padron, Rodrigo and de Vega reported a study that examined the existence of a cognitive developmental paradox in the counterfactual evaluation of decision-making outcomes (Padron et al., 2016); Buenache used counterfactual analysis to simulate the consequences of several monetary policy paths on the key macroeconomic indicators and to identify the optimal exit strategy from the nonstandard monetary environment regarding its timing and magnitude (Buenache, 2016); Jones and Lewis worked on estimating the counterfactual impact of conservation programs on land cover outcomes (Jones \& Lewis, 2015); Bottou and Peters described practical counterfactual analysis techniques applicable to many reallife machine learning systems (Bottou \& Peters, 2013).

In view of the criteria of behaviour change, homogeneous, repeatability and sufficient number of beneficiaries, it has been determined that the tools of the counterfactual impact evaluation are appropriate for the evaluation of measure "Procesas LT" of priority 2.2 "Increasing Business Productivity and Improving Business Environment" of the Operational Programme for Economic Growth.

To determine whether the counterfactual methods can be applied to the particular intervention, the four key attributes have been evaluated:

1. Behaviour change. In order to evaluate the impact of the intervention it is necessary to identify a clear criterion that would make it possible to assess whether the behaviour of entities belonging to the target group has changed. With the purpose of evaluation of the impact of measure "Procesas LT" of priority 2.2 "Increasing Business Productivity and Improving Business Environment" of the Operational Programme for Economic Growth (the measure is intended to encourage small and medium-sized enterprises to introduce modern management methods and management systems, thus creating favourable conditions for increasing enterprise labour productivity and export), the labour productivity indicators are analysed, showing the change in corporate behaviour.

2. Homogeneity. The counterfactual impact evaluation can be carried out only with regard to interventions that are properly homogeneous. It means that the entities shall be engaged in the identical or comparable activities which pursue the same objectives. Besides, homogeneous interventions are based on the equivalent intervention logic. The activities supported by measure "Procesas LT" comprise implementation of modern management methods and management systems, except of personnel management systems". This research is focused on the counterfactual impact evaluation of the organisations that have been granted the support for the implementation and certification of the Occupational Health and Safety Management Systems 
compliant with the requirements of OHSAS 18001; therefore, it can be stated that the analysed intervention is homogeneous.

3. Repeatability. The counterfactual impact evaluation provides the information necessary for deciding whether the intervention should be continued and its scope expanded. If the intervention is unique, it is not possible to apply the results of the counterfactual impact evaluation for improvement of new interventions; therefore, such evaluation is not significant. In the course of this research the counterfactual impact evaluation is carried out with the intention of comparing the economic indicators (labour productivity) of the enterprises. Whereas after the intervention not all enterprises operating in Lithuania will have the management systems implemented according to the requirements of the international standards; and in view of the prerequisite that in the course of the new financial perspective (2014-2020) further support is planned for the implementation of innovative management methods, it can be presumed that there are all conditions for repeatability.

4. Number of beneficiaries. For the purpose of this research the target group is Lithuanian organisations operating in the construction sector that have been granted the support and have implemented the projects under measure "Procesas LT", which provide for the implementation and certification of the Occupational Health and Safety Management Systems in accordance with the requirements of international standard OHSAS 18001. In 20125.945 enterprises were operating in the construction sector, including 4.360 very small (from 1 to 9 employees), 1.283 small (from 10 to 49 employees), 264 medium-sized (from 50 to 249 employees) and 38 large (over 250 employees) enterprises. The enterprises of the construction sector that have been granted the support under measure "Procesas Lt" and implemented and certified the Occupational Health and Safety Management System in accordance with the requirements of OHSAS 18001, include 1 very small enterprise, 6 small enterprises (all of them submitted the applications in 2012), and 3 medium-sized enterprises (2 of them submitted the applications in 2012). The research further narrows to the analysis of the small and medium-sized enterprises that submitted the applications in 2012, thus amounting to 8 enterprises. The control group encompasses the organisations representing the construction sector, which are differentiated by their size. The relatively small amount of the beneficiaries in the overall proportion of the sector enterprises ensures credibility of the outcome, by integrating the results of the target group into the results of the control group.

Multi-criteria decision-making method could be also used for the research, still there are no possibilities to get relevant data.

\section{Counterfactual Impact Evaluation of Measure "Procesas LT" in Enterprises of the Construction Sector}

The conformity of all the attributes with the application requirements of the counterfactual impact evaluation method provides the basis for conducting the counterfactual impact evaluation of the support under measure "Procesas LT" of priority 2.2 "Increasing Business Productivity and Improving
Business Environment" of the Operational Programme for Economic Growth in the organisations of the construction sector, which have utilised the funding for the implementation and certification of the Occupational Health and Safety Management System compliant with the requirements of OHSAS 18001.

In measuring labour productivity of a sector of the domestic economy, the amount of the gross value added created is used to represent the volume of production. The Department of Statistics of Lithuania applies the same principle for calculating labour productivity of a sector of the domestic economy that is used in the European System of National and Regional Accounts (ESA 95), according to which the compilation of statistics of the national accounts across the EU follows the same common internationally recognized definitions and rules. In this method labour productivity is expressed as the gross value added created per hour actually worked per employee (Formula 1) (Department of Statistics of Lithuania, 2009).

Labour productivity $=$ Gross value added/Number of hours actually worked (1)

Accordingly,

Gross value added $=$ Labour productivity $*$ Number of hours actually worked (2)

This calculation method is used for the impact evaluation of measure "Procesas LT" of priority 2.2 "Increasing Business Productivity and Improving Business Environment" of the Operational Programme for Economic Growth on changes of the value added in enterprises of the construction sector upon implementation of the Occupational Health and Safety Management System. The calculated labour productivity in small and medium-sized enterprises of the construction sector for the period of 20092013 is provided in Table 2.

Table 2

Labour Productivity in the Construction Sector

\begin{tabular}{|l|c|c|c|c|c|}
\hline & $\mathbf{2 0 0 9}$ & $\mathbf{2 0 1 0}$ & $\mathbf{2 0 1 1}$ & $\mathbf{2 0 1 2}$ & $\mathbf{2 0 1 3}$ \\
\hline Small enterprises, Eur/h & 3,00 & 3,45 & 4,18 & 4,22 & 4,87 \\
\hline $\begin{array}{l}\text { Medium-sized enterprises, } \\
\text { Eur/h }\end{array}$ & 4,77 & 4,83 & 5,25 & 5,54 & 6,24 \\
\hline
\end{tabular}

The calculations show that labour productivity in the small and medium-sized enterprise segments of the construction sector is growing continuously (this growth is conditioned by the macroeconomic factors). During the analysed period labour productivity in the small enterprises of the construction sector increased from 3.00 Eur/h to 4.87 Eur/h, or by $62 \%$; labour productivity in the medium-sized enterprises of the construction sector increased from 4.77 Eur/h to 6.24 Eur/h, or by $31 \%$.

Based on the historical trends and using the extrapolation method, the forecasted change in labour productivity has been calculated in the small and mediumsized enterprises of the construction sector, which is determined by the macroeconomic factors. The calculations are provided in Table 3. 
Laura Baroniene, Vytautas Zirgutis. Counterfactual Impact Evaluation of the Support under Measure "Procesas LT" in ...

Table 3

Table 5

Forecasted Labour Productivity of the Construction Sector

\begin{tabular}{|l|c|c|c|c|}
\hline & $\mathbf{2 0 1 4}$ & $\mathbf{2 0 1 5}$ & $\mathbf{2 0 1 6}$ & $\mathbf{2 0 1 7}$ \\
\hline Small enterprises, Eur/h & 4,88 & 5,05 & 5,20 & 5,31 \\
\hline Change, \% & 0,21 & 3,48 & 2,97 & 2,12 \\
\hline Medium-sized enterprises, Eur/h & 6,02 & 6,18 & 6,29 & 6,37 \\
\hline Change, \% & $-3,53$ & 2,66 & 1,78 & 1,27 \\
\hline
\end{tabular}

The historical and forecasted data of labour productivity are provided in Figure 1.

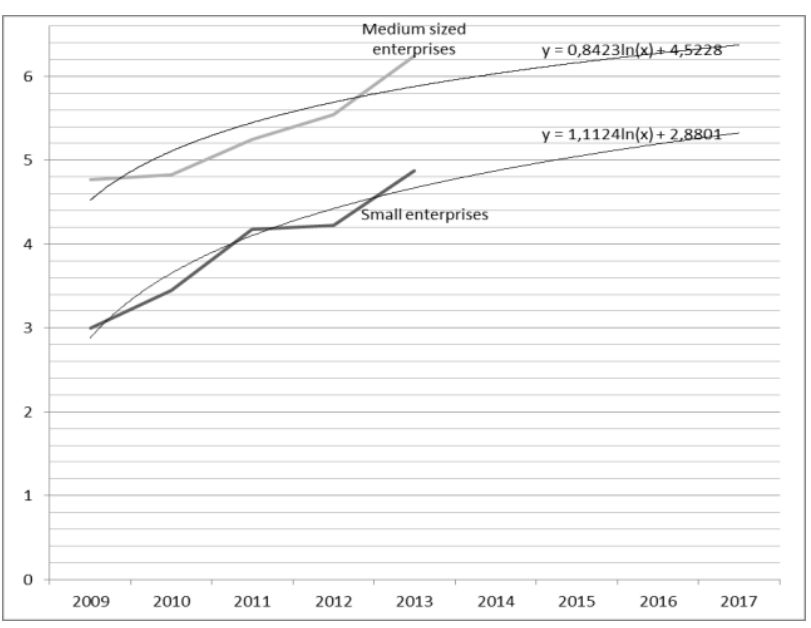

Figure 1. Changes and Forecast of Labour Productivity in the Construction Sector

Based on the historical data of labour productivity in the construction sector, the forecasted labour productivity and the initial data of every single enterprise under research, changes in labour productivity of every single enterprise under research have been calculated as for the period of 2015-2017, by assuming that the factors affecting labour productivity in the entire sector will also affect labour productivity of the enterprises under research, and this effect will be of the same strength. Anonymised calculations are provided in Table 4 (and hereinafter in the text), following the guidelines of the research ethics.

Table 4

Forecasted Labour Productivity of the Enterprises under Research, Considering the Sector-Specific Trends

\begin{tabular}{|l|c|c|c|c|}
\hline \multirow{2}{*}{ Enterprise } & \multicolumn{1}{|c|}{$\begin{array}{c}\text { Actual labour } \\
\text { productivity, Eur/h }\end{array}$} & \multicolumn{3}{|c|}{ Forecasted labour productivity, } \\
& $\mathbf{2 0 1 1}$ & $\mathbf{2 0 1 5}$ & $\mathbf{2 0 1 6}$ & $\mathbf{2 0 1 7}$ \\
\cline { 2 - 5 } & 6,65 & 8,03 & 8,27 & 8,45 \\
\hline M1 & 9,9 & 11,96 & 12,32 & 12,58 \\
\hline M2 & 3,57 & 4,31 & 4,44 & 4,54 \\
\hline M3 & 4,77 & 5,76 & 5,93 & 6,06 \\
\hline M4 & 8,92 & 10,78 & 11,10 & 11,33 \\
\hline M5 & 2,53 & 3,06 & 3,15 & 3,21 \\
\hline M6 & 4,76 & 5,60 & 5,70 & 5,78 \\
\hline V1 & 3,36 & 3,96 & 4,03 & 4,08 \\
\hline V2 & & & the \\
\hline
\end{tabular}

Based on the calculation of the forecasted labour productivity of the enterprises under research (considering the impact of the macroeconomic factors), the forecasted value added has been calculated, to be created by the same enterprises in 2015-2017, by assuming that the number of employees will remain unchanged in the enterprises under research. The calculations are provided in Table 5 (there will be 2016 working hours per each year under research).
Forecasted Value Added Created by the Enterprises under Research (Considering the Macroeconomic Factors)

\begin{tabular}{|c|c|c|c|c|}
\hline \multirow{2}{*}{ Enterprise } & \multirow{2}{*}{$\begin{array}{c}\begin{array}{c}\text { Number of } \\
\text { employees, } \\
\text { pcs. }\end{array} \\
2011 \\
\end{array}$} & \multicolumn{3}{|c|}{ Forecasted value added created, Eur } \\
\hline & & 2015 & 2016 & 2017 \\
\hline M1 & 48 & 777.443 & 800.535 & 817.470 \\
\hline M2 & 44 & 1.060 .947 & 1.092 .460 & 1.115 .570 \\
\hline M3 & 60 & 521.705 & 537.201 & 548.565 \\
\hline M4 & 66 & 766.775 & 789.550 & 806.253 \\
\hline M5 & 19 & 412.785 & 425.046 & 434.037 \\
\hline M6 & 16 & 98.593 & 101.522 & 103.669 \\
\hline V1 & 88 & 994.053 & 1.011 .746 & 1.024 .614 \\
\hline $\mathrm{V} 2$ & 73 & 582.079 & 592.440 & 599.975 \\
\hline \multicolumn{2}{|c|}{ Total: } & 5.214.379 & 5.350 .500 & 5.450 .152 \\
\hline
\end{tabular}

According to the calculations provided, the value added created by the enterprises under research will amount to 16.015.031 Eur as for the period of 2015-2017.

Enterprises applying for the support under measure "Procesas Lt" shall declare the existing labour productivity and undertake to implement modern management method and thus to increase their labour productivity. The accomplishment term of the obligations has been set to 2015. It is assumed that the projects of the implementation of modern management methods funded under measure "Procesas Lt" will be successful: the enterprises that have been granted the support and achieved the project objectives will fulfil the targeted labour productivity obligations. The labour productivity of the enterprises under research will be affected by the macroeconomic factors in 2016 and 2017, as it has already been shown in the previous calculations. The calculations are provided in Table 6.

Table 6

Forecasted Labour Productivity of the Enterprises under Research, Considering the Obligations

\begin{tabular}{|l|c|c|c|}
\hline \multirow{2}{*}{ Enterprise } & $\begin{array}{c}\text { Labour productivity } \\
\text { obligation, Eur/h }\end{array}$ & \multicolumn{2}{|c|}{$\begin{array}{c}\text { Forecasted labour } \\
\text { productivity, Eur/h }\end{array}$} \\
\cline { 2 - 4 } & $\mathbf{2 0 1 5}$ & $\mathbf{2 0 1 6}$ & $\mathbf{2 0 1 7}$ \\
\hline M1 & 8,05 & 8,29 & 8,47 \\
\hline M2 & 10,98 & 11,31 & 11,54 \\
\hline M3 & 5,38 & 5,54 & 5,66 \\
\hline M4 & 5,10 & 5,25 & 5,36 \\
\hline M5 & 11,15 & 11,48 & 11,72 \\
\hline M6 & 2,71 & 2,79 & 2,85 \\
\hline V1 & 5,81 & 5,91 & 5,99 \\
\hline V2 & 5,65 & 5,75 & 5,82 \\
\hline
\end{tabular}

Based on the calculation of the forecasted labour productivity of the enterprises under research (considering the obligations), the forecasted value added has been calculated, to be created by the same enterprises in 20152017, by assuming that the number of employees will remain unchanged in the enterprises under research. The calculations are provided in Table 7 (there will be 2016 working hours per each year under research). 
Table 7

Forecasted Value Added Created by the Enterprises under Research (Considering the Obligations)

\begin{tabular}{|c|c|c|c|c|}
\hline \multirow{2}{*}{ Enterprise } & \multirow{2}{*}{$\begin{array}{c}\begin{array}{c}\text { Number of } \\
\text { employees, } \\
\text { pcs. }\end{array} \\
2011\end{array}$} & \multicolumn{3}{|c|}{ Forecasted value added created, Eur } \\
\hline & & 2015 & 2016 & 2017 \\
\hline M1 & 48 & 779395 & 802546 & 819523 \\
\hline M2 & 44 & 973922 & 1002850 & 1024064 \\
\hline M3 & 60 & 650560 & 669883 & 684054 \\
\hline M4 & 66 & 678285 & 698432 & 713207 \\
\hline M5 & 19 & 427104 & 439790 & 449093 \\
\hline M6 & 16 & 87546 & 90146 & 92053 \\
\hline V1 & 88 & 1030717 & 1049063 & 1062406 \\
\hline $\mathrm{V} 2$ & 73 & 831152 & 845946 & 856705 \\
\hline & Total: & 5.458 .682 & 5.598 .658 & 5.701 .106 \\
\hline
\end{tabular}

According to the calculations provided and considering the obligations undertaken, the value added created by the enterprises under research should amount to 16.758.445 Eur as for the period of 2015-2017. This amount is $4.64 \%$ higher than the one calculated considering the effect of the macroeconomic factors. In order to identify the impact of measure "Procesas Lt", the counterfactual comparison has been carried out with regard to every single enterprise under research; the calculations are provided in Table 8.

Table 8

Counterfactual Comparison of Measure "Procesas Lt"

\begin{tabular}{|c|c|c|c|}
\hline Enterprise & $\begin{array}{c}\text { Forecasted } \\
\text { value added } \\
\text { created in 2015- } \\
\text { 2017, } \\
\text { considering the } \\
\text { sector-specific } \\
\text { trends, Eur }\end{array}$ & $\begin{array}{c}\text { Forecasted value } \\
\text { added created in } \\
\mathbf{2 0 1 5 - 2 0 1 7} \\
\text { considering the } \\
\text { obligations, Eur }\end{array}$ & $\begin{array}{c}\text { Counterfactual } \\
\text { comparison }\end{array}$ \\
\hline M1 & 2.395 .448 & 2.401 .464 & 6.016 \\
\hline M2 & 3.268 .976 & 3.000 .836 & -268.139 \\
\hline M3 & 1.607 .472 & 2.004 .497 & 397.026 \\
\hline M4 & 2.362 .578 & 2089.925 & -272.653 \\
\hline M5 & 1.271 .869 & 1.315 .987 & 44.118 \\
\hline M6 & 303.784 & 269.746 & -34.038 \\
\hline V1 & 3.030 .412 & 3.142 .186 & 111.774 \\
\hline V2 & 1.774 .493 & 2.533 .803 & 759.310 \\
\hline & & Total: & $\mathbf{7 4 3 . 4 1 4}$ \\
\hline
\end{tabular}

The calculations have shown that three enterprises (M2, M4 and M6) had undertaken extremely conservative obligations to increase labour productivity, while applying for the support for implementation of modern management methods: even if they had not managed to implement the projects, the forecasted value added created in these enterprises would have been higher, alone due to the macroeconomic factors affecting the sector. Three other enterprises (M1, M5 and V1) had undertaken rather conservative obligations to increase labour productivity: even if they had not managed to implement the projects, the forecasted value added created in these enterprises would have been similar, alone due to the macroeconomic factors affecting the sector. And only two enterprises (M3 and V2) had undertaken ambitious obligations to increase the labour productivity: upon implementation of the projects the forecasted value added created in these enterprises would be much higher than the one in case of failure to implement the projects.
The overall arithmetic counterfactual impact of measure "Procesas Lt" for the enterprises is 743.414 Euro during the analysed period. The amount of 26.768 Euro has been allocated for the project implementation in the enterprises under measure "Procesas Lt". Hence, one Euro of the support has enabled creation of the value added amounting to 27.8 Euro within three years (or respectively the average of 9.3 Euro per year). Assuming that the organisations that have adopted conservative decisions regarding labour productivity had not been convinced of the success of the project under implementation or had not expected that the project would provide additional preconditions for increasing labour productivity in comparison with the market conditions, it can be concluded that only the enterprises that have undertaken ambitious obligations regarding labour productivity have derived a benefit under measure "Procesas LT". The said enterprises have been granted the support of 5.419 Euro. Hence, one Euro of the support has enabled creation of the value added amounting to 210 Euro within three years (or respectively the average of 70 Euro per year).

The research refers to the calculations that are based on the necessary assumptions. These assumptions may be validated or negated. The authors of the research intend to proceed with the research in 2018 , when it will be possible to refer not to the forecasted trends of labour productivity in the construction sector, but the actual values thereof; and not to the forecasted value added created in the enterprises under research, but the actual one. Given the real values, the retrospective evaluation of the benefit of the implemented projects of modern management methods in the enterprises under research and the effectiveness of the funding utilisation under measure "Procesas Lt" will be possible in the analysed cases.

\section{Conclusions}

Competitiveness of the State and social welfare depend on labour productivity and effectiveness of the available industry and enterprises. This dependence is particularly evident in small open economies, such as Lithuania. Changes in the macro-level factors are associated with the measures implemented at the national level and the impact of the international business environment, while the fluctuation of the micro-level factors can also be influenced by the investments of the EU Structural Funds.

Measure "Procesas LT" was supposed to contribute to implementation of the goal to increase corporate labour productivity. Enterprises applying for the support under the measure shall undertake to implement modern management method and to increase labour productivity. However, there is no objective evidence showing to what extent the obligations undertaken by the enterprises that have been granted the support are real (where increase in labour productivity is actually planned because of the implemented management method) or formal (where labour productivity will be changed due to macro-level factors). In the absence of the evidence it is difficult to assess the effectiveness of the EU support funds utilised under measure "Procesas Lt".

Based on the historical trends and using the extrapolation method, the forecasted change in labour productivity has been calculated in the small and medium- 
sized enterprises of the construction sector, which is determined by the macroeconomic factors. Since the macroeconomic factors affect all enterprises of the sector, the forecasted labour productivity has been calculated; assuming that the number of employees will remain unchanged in the enterprises, the value added has been forecasted with regard to the enterprises of the construction sector that have been granted the support under measure "Procesas LT" for implementation Management System compliant with the requirements of OHSAS 18001, which has amounted to 16.015.031 Euro as for the period of 20152017 (excluding the change in labour productivity due to the implemented modern management method). Assuming that the implementation projects of the Occupational Health and Safety Management Systems will be successful, the value added to be created by the same enterprises has been calculated, considering the undertaken obligations to increase labour productivity, which has amounted to 16.758.445 Euro.

Three enterprises have undertaken extremely conservative obligations to increase labour productivity, while applying for the support for implementation of modern management methods: even if they had not managed to implement the projects, the forecasted value added created in these enterprises would have been higher, alone due to the macroeconomic factors affecting the sector. Three other enterprises have undertaken rather conservative obligations to increase the labour productivity: even if they had not managed to implement the projects, the forecasted value added created in these enterprises would have been similar, alone due to the macroeconomic factors affecting the sector. And only two enterprises have undertaken ambitious obligations to increase the labour productivity: upon implementation of the projects the forecasted value added created in these enterprises would be much higher than the one in case of failure to implement the projects. Managerial decision to undertake obligations leads to the risk, but the decision to grant funding depends not only on the foreseen productivity, therefore is visible trend to undertake small obligations.

The overall arithmetic counterfactual impact of measure "Procesas Lt" for these enterprises is 743.414 Euro during the analysed period. The amount of 26.768 Euro has been allocated for the project implementation in the enterprises under measure "Procesas Lt". Hence, one Euro of the support has enabled creation of the value added amounting to 27.8 Euro within three years (or respectively the average of 9.3 Euro per year). Public decision to grant funding in the construction sector leads to the achieved income of 9.3 Euro from 1.0 Euro of funding, but there is no knowledge of the income gained from 1.0 Euro of funding in the enterprises of other sectors, which received the funding. The comparative analysis could be made to calculate the best public decisions seeking more benefit from funding. The results could be used as recommendations for the public-sector enterprises that are responsible for funding distribution.

The research refers to the calculations that are based on the necessary assumptions. These assumptions may be validated or negated. The authors of the research intend to proceed with the research in 2018 , when it will be possible to refer not to the forecasted trends of labour productivity in the construction sector, but to the actual values thereof; and not to the forecasted value added created in the enterprises under research, but the actual one. Given the real values, the retrospective evaluation of the benefit of the implemented projects of modern management methods in the enterprises under research and the effectiveness of the funding utilisation under measure "Procesas Lt" will be possible in the analysed cases.

\section{References}

Barro, R. J., \& Sala-i-Martin, X. (2004). Economic growth. Cambridge, MA, and London: MIT Press.

Baumol, W. J., Nelson, R. R., \& Wolff, E. N. (1994). Convergence of productivity: Cross-national studies and historical evidence. Oxford: Oxford University Press.

Bernard, A., Jensen, J., Redding, S., \& Schott, P. (2007), Firms in International Trade. Journal of Economic Perspectives. American Economic Association, 21(3). https://doi.org/10.3386/w13054

Bernard, A. B., \& Jones, C. I. (1996)a. Comparing apples to oranges: Productivity convergence and measurement across industries and countries. American Economic Review 86, 1216-38.

Bernard, A. B., \& Jones, C. I. (1996)b. Technology and convergence. Economic Journal 106, $1037-44$. https://doi.org/10.2307/2235376

Berzkalne, I., \& Zelgalve, E. (2012). Innovation and company value: evidence from the Baltic countries. Regional Formation and Development Studies, 3(11), 39-51.

Biondi, S., Calabrese, A., Capece, G., Costa, R., \& Pillo, F. Di. (2013). A New Approach for Assessing Dealership Performances: an application to the Automotive Industry. International Journal of Engineering Business Management. Forthcoming. https://doi.org/10.5772/56662

Blazek, L. et al. (2007). Competitiveness of enterprises (Primary analysis of empirical survey results). Brno: Masaryk University.

Blazek, L. et al. (2009). Competitiveness of enterprises. Analysis of economic success factors. Second stage. Brno: Masaryk University

Bondoc, M. D., \& Hagiu, A. (2011). SMEs Competitiveness Reflected Through Productivity-Comparative Study Between Romania and the EU. Euro Economica, 5 (30), 137-147. 
Borensztein, E., \& Ostry, J. D. (1996). Accounting for China's growth performance. The American Economic Review 86, 224-228.

Bottou, L., \& Peters, J. (2013). Counterfactual Reasoning and Learning Systems: The Example of Computational Advertising. Journal of Machine Learning Research 14 3207-3260.

Buenache, G. L. (2016). Monetary policy evaluation. A counterfactual analysis based on dynamic factor models. Applied Economics Letters. Published online: 08 Jul 2016: pages 1-7.

Calabrese, A, Costa, R, \& Menichini, T. (2013a). Using fuzzy AHP to manage intellectual capital assets: an application to the ICT service industry. Expert Systems with Applications, 40 (9), 3747-3755. https://doi.org/10.1016/j.eswa. 2012.12.081

Cameron, G., Proudman, J., \& Redding, S. (2005). Technological convergence, R\&D, trade and productivity growth. European Economic Review, 49, 775-807. https://doi.org/10.1016/S0014-2921(03)00070-9

Capece, G., Cricelli, L., Pillo, F. Di, \& Levialdi, N. (2008). A Productivity Analysis of the Italian Gas Retail Market (43 52). Environmental Economics and Investment Assessment II, Southampton: WIT Press.

Change, S. J., Hsiao, H. C., Huang, L. H., \& Chang, H. (2011). Taiwan quality indicator project and hospital productivity growth. Omega, 39 (1), 14-22. https://doi.org/10.1016/j.omega.2010.01.006

Cho, J. O., \& Cooley, T. F. (2005). Business Cycle Uncertainty and Economic Welfare. New York University, Working Paper.

Chow, G. C., \& Li, K. W. (2002). China's Economic Growth: 1952-2010. Economic Development and Cultural Change, 51, 247-256. https://doi.org/10.1086/344158

Costa, R. (2012). Assessing Intellectual Capital Efficiency and Productivity: An Application to the Italian Yacht Manufacturing Sector. Expert Systems with Applications, 39 (8), 7255-7261. https://doi.org/10.1016/j.eswa. 2012.01.099

Garcia-Cicco, J., Pancrazi, R., \& Uribe, M. (2010). Real Business Cycles in Emerging Countries? American Economic Review 100(5), 2510-31. https://doi.org/10.1257/aer.100.5.2510

Gronroos, C., \& Ojasalo, K. (2004). Service Productivity: Towards a conceptualization of the Transformation of Inputs into Economic Results in Services. Journal of Business Research 57, 414-423. https://doi.org/10.1016/S01482963(02)00275-8

Hottenrott, H., \& Lawson, C. (2013). Fishing for Complementarities: Competitive Research Funding and Research Productivity. ZEW - Centre for European Economic Research Discussion Paper No. 13-113. Available at SSRN: https://ssrn.com/abstract=2379436 or http://dx.doi.org/10.2139/ssrn.2379436

Hu, A. G., \& Liu, Z. (2014). Trade Liberalization and Firm Productivity: Evidence from Chinese Manufacturing Industries. Review of International Economics, 22(3), 488-512. https://doi.org/10.1111/roie.12127

Hulten, C. (2001). Total Factor Productivity: A Short Biography. New Developments in Productivity Analyses. ChicagoUniversity of Chicago Press. https://doi.org/10.7208/chicago/9780226360645.003.0001

Jones, K. W., \& Lewis, D. J. (2015). Estimating the Counterfactual Impact of Conservation Programs on Land Cover Outcomes: The Role of Matching and Panel Regression Techniques. PLoS ONE 10(10): e0141380. Published: October 26, 2015; doi:10.1371/journal.pone.0141380. https://doi.org/10.1371/journal.pone.0141380

Komarkova, L., Pirozek, P., \& Pudil, P. (2014). The Factors and Other Characteristics Influencing Competitiveness of Enterprises in Countries in the Post-Transition Phase of the Economy. Inzinerine Ekonomika-Engineering Economics, 25(5), 513-521. 9p. 5 Charts. https://doi.org/10.5755/j01.ee.25.5.3136.

Krugman, P. (1994). Myth of Asia's Miracle. Foreign Affairs 73, 62-78. https://doi.org/10.2307/20046929

Laureti, T., \& Viviani, A. (2011). Competitiveness and productivity: a case study of Italian firms. Applied Economics, 43(20), 2615-2625. 11p. 8 Charts. https://doi.org/10.1080/00036840903357439

Lechman, E. (2014). Changing Patterns in the Export of Goods Versus International Competitiveness. A Comparative Analysis for Central-East European Countries in the Period 2000-2011. Comparative Economic Research. 17(2), 61-77. 17p. https://doi.org/10.2478/cer-2014-0014

Lee, P. K. C., Cheng, T. C. E., Yeung, A. C. L., \& Lai, K. H. (2011). An Empirical Study of Transformational Leadership, Team Performance and Service Quality in Retail Banks. Omega, 39, 690-701. https://doi.org/10.1016/ j.omega.2011.02.001

Leon-Ledesma, M., McAdam, P., \& Willman, A. (2010) Identifying the elasticity of substitution with biased technical change. American Economic Review, 100, 1330-57. https://doi.org/10.1257/aer.100.4.1330

Makin, A. J., \& Strong, S. (2013). New measures of factor productivity in Australia: a Sato approach. Applied Economics, 45(17), 2413-2422. https://doi.org/10.1080/00036846.2012.665603 
Laura Baroniene, Vytautas Zirgutis. Counterfactual Impact Evaluation of the Support under Measure "Procesas LT” in ...

Manole, D. S., Nisipeanu, E., Decuseara, R. (2014). Study on the competitiveness of Small and Medium $\neg$ sized Enterprises (SMEs) in Valcea County. Theoretical \& Applied Economics, 21(4), 113-130. 18p.

Marinova, D., J., \& Ye, Singh, J. (2008). Do Frontline Mechanisms Matter? Impact of Quality and Productivity Orientations on Unit Revenue, Efficiency and Customer Satisfaction. Journal of Marketing, 72(2), 28-45. https://doi.org/10.1509/jmkg.72.2.28

Miller, S. M., \& Upadhyay, M. P. (2002). Total factor productivity and the convergence hypothesis. Journal of Macroeconomics 24, 267-86. https://doi.org/10.1016/S0164-0704(02)00022-8

Minister of Economy of the Republic of Lithuania. (2012). Order No. 4-508.

Ostrom, A. L., Bitner, M. J. Brown, S. W. Burkhard, K. A. Goul, M. Smith-Daniels, V. Demirkan, H., \& Rabinovich, E. (2010). Moving Forward and Making a Difference: Research Priorities for the Science of Service. Journal of Service Research 13(1), 4-36. https://doi.org/10.1177/1094670509357611

Padron, I., Rodrigo, M. J., \& de Vega, M. (2016). Counterfactual Evaluation of Outcomes in Social Risk DecisionMaking Situations: The Cognitive Developmental Paradox Revisited. Advances in cognitive psychology, 12(1), 1019. Published online 2016 Mar 31. https://doi.org/10.5709/acp-0183-2

Porter, M., \& Ketels, C. (2003). UK competitiveness: moving to the next stage, DTI, Economic Papers no. 3, ESRC. Available at: http://www.esrc.ac.uk/_images/UK_competitiveness_tcm8-13559.pdf. Accessed on February 25, 2013.

Porter, M. E., Delgado, M., Ketels, C., \& Stern, S. (2008), Moving to a New Global Competitiveness Index, in World Economic Forum (ed.). The Global Competitiveness Report 2008-2009.

Preenen, P., Vergeer, R., Kraan K., \& Dhondt, S. (2015). Labour productivity and innovation performance: The importance of international labour flexibility practices. Economic and Industrial Democracy, 1-23.

Results of Impact of the EU Structural Support on the Competitiveness of Lithuania (2015).

Rizov, M., Pokrivcak, J., \& Ciaian, P. (2013). CAP Subsidies and Productivity of the EU Farms. Journal of Agricultural Economics. 64(3), 537-557. https://doi.org/10.1111/1477-9552.12030

Ruan, J., \& Gopinath, M. (2010). Technological convergence, competitiveness, and welfare: A study of international manufacturing industries. Journal of International Trade \& Economic Development. 19(4), 517-551. 35p. 4 Charts. https://doi.org/10.1080/09638199.2010.506331

Shepotylo O., \& Vkhitov, V. (2015). Services liberalization and productivity of manufacturing firms: Evidence from Ukraine. Economics of Transition. 23(1), 1-44. https://doi.org/10.1111/ecot.12061

Spencer, B., \& Brandner, J. (2008), Strategic Trade Policy, in: The New Palgrave Dictionary of Economics, ed. by S.N. Durlauf and L. E. Blume, Basingstoke, Hampshire: Palgrave Macmillan.

Staskeviciute, G., \& Tamosiuniene, R. (2010). Salies konkurencingumas: sampratos raida laiko perspektyvoje. Verslas: teorija ir praktika, 11 (2), 159-167. https://doi.org/10.3846/btp.2010.18

Statistics of Lithuania. (2009). Vilnius: Department of Statistics of Lithuania.

Stredna, L., \& Zubkova, M. (2012). The Position of Slovakia in Competitiveness Ranking - the Causes, Impacts and Prospects. Business, Management and Education 10(1), 38-49.

Syverson, C. (2011). What Determines Productivity? Journal of Economic Literature, 49(2), 326-365.

Vijeikis, J., \& Makstutis, A. (2009). Small and Medium-sized Business Competitiveness in Lithuania. Ekonomika ir vadyba: aktualijos ir perspektyvos 15(2), 328-338.

Yu, M. (2010). China's Trade Liberalization and Productivity of Manufacturing Enterprises. Economic Studies 12, $97-$ 100.

Yu, M. (2015). Processing Trade, Tariff Reductions and Firm Productivity: Evidence from Chinese Firms. The Economic journal, 125(585), 943-988. https://doi.org/10.1111/ecoj.12127

Yu, M., \& Li, J. (2014). Imported Intermediate Inputs, Firm Productivity and Product Complexity. The Japanese Economic Review, 65(2), 178-192. https://doi.org/10.1111/jere.12041

The article has been reviewed.

Received in November, 2015; accepted in October, 2017. 